\title{
Radical Cystectomy Procedures in Fatmawati General Hospital, Jakarta, Indonesia: Preliminary Report
}

\author{
Syamsu Hudaya, Karina Evelyn Sidabutar \\ Department of Surgery, Fatmawati General Hospital, Jakarta, Indonesia
}

\section{ARTICLE INFO}

Received : 19 November 2019

Reviewed: 07 January 2019

Accepted : 04 February 2019

Keywords:

Ileal conduit, Indonesia, radical

cystectomy

\begin{abstract}
Background: Radical cystectomy (RC) and urinary diversion (UD) are among the most complex urological procedures with high postoperative morbidity, That caused only a few urologists are prepared to perform this operation. We dedicated to enroll this procedure since the number of bladder tumor cases is increasing in our third referral general hospital. We evaluate and analyze variables related to the surgical and direct post-operative outcomes of our initial experience of radical cystectomy.
\end{abstract}

\begin{abstract}
Methods: This retrospective descriptive study collected medical record of patients with RC in Fatmawati Hospital, Jakarta, Indonesia from 2014-2016. All surgeries were performed by the same surgeon. Variables related to the surgical and postoperative outcomes and complications in the patients were analyzed.
\end{abstract}

Results: There were 11 patients during this study period. The average age of the patients was $60.9 \pm 9.6$ years old with 7 male and 4 female patients. All patients underwent ileal conduit as urinary diversion. The mean operation time was $392.7 \pm 117$ minutes. The estimated blood loss was $1,272.7 \pm 538.7 \mathrm{~mL}$. No intraoperative death was recorded. The hospital stay length was $15.8 \pm 8.3$ days, visual analog scale (VAS) score in the first day after surgery was $2.7 \pm 0.2$, and the drain was kept in for $13.9 \pm$ 7.4 days. All of the histopathology results were urothelial carcinomas.

\section{*Corresponding author:}

Syamsu Hudaya

Department of Surgery, Fatmawati General Hospital, Jakarta, Indonesia shudaya.15@gmail.com
Conclusions: Our initial experience with radical cystectomy results in acceptable blood loss, manageable post-operative pain, and acceptable hospital stay. Therefore it is still a treatment of choice for muscle-invasive bladder cancer in our hospital.

\section{INTRODUCTION}

Bladder cancer $(\mathrm{BC})$ is the 11th most common cancer in the world and the 7th leading cause of death in cancer population. In Indonesia, it is the 12th leading cancer in the population. Bladder cancer is one of the common cancers of both sexes in Indonesia. The incidence increased $\sim 15 \%$ per year in the last decade, with transitional cell carcinoma (TCC) as the most common histological type (78.8\%), followed by squamous cell carcinoma (SCC) (10.2\%), adenocarcinoma (8.6\%), and sarcoma (2.4\%). Data from the two tertiary referral hospitals showed that more patients were diagnosed with muscle-invasive bladder cancer (MIBC). Some of these patients came in the later stage because of the patient's lack of awareness and their tendency to seek alternative traditional medicine such as herbals before seeking professional healthcare advice. Muscle-invasive bladder cancer is an aggressive disease. Its 2-year-mortality rate is more than $85 \%$ when untreated (1).
The gold standard for diagnosing MIBC and high grade non-muscle invasive bladder cancer recurrence after transurethral resection of the bladder (TUR-B) and intravesical instilation is still open radical cystectomy (RC) (2). Aside from removing the bladder, perivesical fat and pelvic lymph nodes, the standard technique for $\mathrm{RC}$ also removes the prostate and seminal vesical in men as well as uterus, tube, and ovaries in women (3). Radical cystectomy is one of the most complex urological procedures with high postoperative morbidity. Complication rates, however, vary between studies and are reported to be $28 \%$ to $65 \%$. The use of small intestine segment usually distal part of the ileum (ileal conduit) is the most common urinary diversion procedure contributing to $33-72 \%$ of all types of urinary diversion (UD) with RC (5). The basic principle of any reconstruction after an oncological procedure is not to compromise.

Fatmawati General Hospital is a third referral hospital located in South Jakarta, Indonesia. Many cases of cancer were referred to this hospital including 
bladder carcinoma. In this study, we reported the outcomes of RC procedure on bladder carcinoma in our hospital.

\section{METHODS}

We collected data retrospectively in our hospital medical record from early 2014 to 2016 . The inclusion criteria were $\mathrm{BC}$ patient who underwent conventional RC during the study period. All procedures were performed by the same urologist. Demographic data including age, gender, body weight and body mass index (BMI) were recorded. We evaluated the demographic data, intraoperative and postoperative parameters of our patients. Intraoperative parameters comprised of method of urinary diversion, operative time, estimated blood loss and intraoperative death. Post-operative parameters were visual analog scale (VAS) score, epidural analgesia use, drain use, length of stay, reoperation rate and postoperative death. All data were analyzed using SPSS 21 .

\section{RESULTS}

\section{Patient population and baseline data}

There were 11 subjects who underwent conventional RC in our center within 2014-2016. Of the 11 patients, 7 (63\%) were males and 4 (37\%) were females. The mean age, body weight, and BMI of the patients was $60.9 \pm 9.6$ years, $46.5 \pm 9.3 \mathrm{~kg}$, and $18.8 \pm$ 3.5 respectively. All the patients have diagnosed by histopathology result as urothelial carcinoma.

Table 1. Patients characteristics

\begin{tabular}{llll}
\hline Characteristics & & N (\%) & Mean \pm SD \\
\hline Age (years) & Male & $7(63)$ & $60.9 \pm 9.6$ \\
Gender & Female & $4(37)$ & \\
& & & $46.5 \pm 9.3$ \\
Body weight $(\mathrm{kg})$ & & & $18.8 \pm 3.5$ \\
BMI (kg/m $\left.{ }^{2}\right)$ & Urothelial ca & $11(100)$ & \\
Histopathology & Uro &
\end{tabular}

BMI: Body Mass Index; Ca: Carcinoma

Table 2. Summary of breast cancer surgery

\begin{tabular}{|c|c|c|c|}
\hline Parameters & & $\mathbf{N}(\%)$ & Mean \pm SD \\
\hline $\begin{array}{l}\text { Method of Urinary } \\
\text { Diversion }\end{array}$ & $\begin{array}{l}\text { Ileal } \\
\text { Conduit }\end{array}$ & $11(100)$ & \\
\hline $\begin{array}{l}\text { Operative time } \\
\text { (minutes) }\end{array}$ & & & $392.7 \pm 117$ \\
\hline $\begin{array}{l}\text { Estimated blood loss } \\
(\mathrm{mL})\end{array}$ & & & $1272.7 \pm 538.7$ \\
\hline \multirow[t]{2}{*}{ Intraoperative death } & Yes & 0 & \\
\hline & No & $11(100)$ & \\
\hline
\end{tabular}

Table 3. Post-operative parameters $(\mathrm{N}=11)$

\begin{tabular}{|c|c|c|c|}
\hline Parameters & & $\mathbf{N}(\%)$ & Mean \pm SD \\
\hline $\begin{array}{l}\text { VAS (first day after } \\
\text { surgery) }\end{array}$ & & & $2.7 \pm 0.2$ \\
\hline \multirow[t]{2}{*}{ Epidural analgesia } & Yes & $1(9)$ & \\
\hline & No & $10(91)$ & \\
\hline $\begin{array}{l}24 \text { hour drain } \\
\text { production }(\mathrm{mL})\end{array}$ & & & $300(70-1950)^{*}$ \\
\hline Drain use (days) & & & $13.9 \pm 7.4$ \\
\hline $\begin{array}{l}\text { Length of } \\
\text { hospitalization } \\
\text { (days) }\end{array}$ & & & $15.8 \pm 8.3$ \\
\hline \multirow[t]{2}{*}{ Re-operation } & Yes & $1(9)$ & \\
\hline & No & $10(91)$ & \\
\hline \multirow{2}{*}{$\begin{array}{l}\text { Post-operative } \\
\text { death }\end{array}$} & Yes** & $4(37)$ & \\
\hline & No & $7(63)$ & \\
\hline
\end{tabular}

\section{DISCUSSION}

The average age of patients who underwent radical cystectomy in this study was $60.9 \pm 9.6$ years old which was slightly younger compared to other studies (7). Several studies reported that RC procedure can be performed on elderly patients over the age of 60 years with good results (8). The 90-days mortality of RC ranges from $5-10 \%$ (9). Elderly patient ( $>65$ years old), however, have higher mortality and morbidity rate. The surveillance, epidemiology, and end results (SEER) database, a population-based data repository in the USA, indicates the 90-day mortality of $6.5,10.4$ and 14.3 $\%$ in age groups 65-69, 70-79 and $>80$ years old, respectively (10). The consensus of the transplant experts in the UK recommends that age alone is not an absolute contraindication but patients aged over 60 years should undergo a thorough suitability assessment. lleal conduit is the most commonly performed urinary diversion following RC. It is associated with acceptable morbidity and has the lowest reoperation rates as compared to continent diversion. It is also the procedure of choice for most elderly patients as well as patients with limited dexterity, poor motivation, anatomical restrictions and poor renal function. Studies measuring health-related quality of live (HRQOL) report excellent patient acceptability, especially in the elderly population (8).

The average $\mathrm{BMI}$ is $18.8 \pm 3.5$ which shows that most of our patients are malnourished. Malnutrition is not a contraindication for RC procedure. However, patients with malnutrition have worse result in recovery. The nutritional status measured by albumin levels is a predictor of RC survival (11). It is clearly highlighted in the early recovery after surgery (ERAS) protocol that the patient should be metabolically and nutritionally 
prepared for surgery.12 A few days before the surgery, the patient received an easily digestible diet, and the last meal was served in the evening before surgery. In addition, the evening before and in the morning of the surgery, the patient should intake carbohydrates containing fluids. It has been proven that the mentioned steps prevent increased catabolic processes, tissue insulin resistance and result in a faster return to normal functioning after surgery $(13,14)$.

The average operative time in this study was $392.7 \pm$ 117 minutes. This is longer than other published studies. The shorter length of operation in the other studies was due to more experience they had. In contrast to the length of operation, the average intraoperative bleeding in this study was $1272.7 \pm 538.7 \mathrm{ml}$, slightly higher than other studies $(15,16)$. Along with the increasing RC procedures performed in our center, the quality and duration of RC are expected to improve. In this study, after the operation, only one patient was given epidural analgesia. Most of the patients did not require epidural analgesia. The first-day pain post-RC procedure assessed, the VAS revealed an average value of $2.7 \pm$ 0.2 . While other study stated the use of combined epidural and spinal analgesia (17).

The average length of hospitalization was $15.8 \pm 8.3$ days. This is comparable to other studies with more experienced team (18). Of all 11 patients, one was reoperated due to bleeding after surgery. Four patients died postoperatively when they were still in the intensive care unit (36\%). This number is higher than in other studies (19). All causes of death in this study was septicemia. Many factors can contribute to this high number such as long surgery time, long hospitalization, and other complications regarding the procedure itself and the cancer.

\section{CONCLUSION}

Our initial experience of radical cystectomy results in acceptable blood loss, manageable post-operative pain, and acceptable hospital stay. Therefore, it is still the treatment of choice for muscle-invasive bladder cancer in our third referral general hospital. We aim to improve our RC outcomes by gaining more experience.

\section{DECLARATIONS}

\section{Competing of Interest}

The authors declare that they have no competing interests.

\section{Acknowledgment}

No acknowledgment statement for this study

\section{REFERENCES}

1. Rainy Umbas, Ferry S, Chaidir AM, Wahjoe D, Agus Rizal AHM. Urological cancer in Indonesia. Jpn J Clin Oncol. 2015; 45(8): 708-12.

2. Prout GR, Marshall VF. The prognosis with untreated bladder tumors. Cancer. 1956. 9(3): 551 8.

3. Ghoneim MA, Abdel-Latif A, el-Mekresh $M$, AbolEnein $\mathrm{H}$, Mosbah A, Ashamalah A, et al. Radical cystectomy for carcinoma of bladder: 2720 consecutive cases 5 years later. J Urol. 2008; 180(1): 121-7.

4. Skinner EC, Stein JP, Skinner DG. Surgical benchmarks for the treatment of invasive bladder cancer. Urol Oncol.2007;25 (1): 66-71.

5. Patel HD, Ball MW, Cohen JE, Kates M, Pierorazio PM, Allaf ME. Morbidity of urologic surgical procedures: an analysis of rates, risk factors, and outcomes. Urology.2015;85(3): 552-9.

6. Hautmann RE, Abol-Enein $\mathrm{H}$, Hafez K, Haro I, Mansson W, Mills RD, et al. Urinary diversion. Urology.2007; 69 (1 Suppl): 17-49.

7. Patel MI, Bang A, Gillatt D, Smith DP. Contemporary radical cystectomy outcomes in patients with invasive bladder cancer: a population-based study. BJU Int. 2015; 116(Suppl 3): 18-25.

8. Siddiqui KM, Izawa JI. Ileal conduit: standard urinary diversion for elderly patients undergoing radical cystectomy. World J Urol. 2016;34(1):19-24.

9. Aziz A, May M, Burger M, Palisaar RJ, Trinh $Q D$, Fritsche $\mathrm{HM}$ et al. Prediction of 90-day mortality after radicalcystectomy for bladder cancer in a prospective European multicenter cohort. Eur Urol. 2014;66(1): 156-63.

10. Schiffmann J, Gandaglia G, Larcher A, Sun M, Tian Z, Shariat SF. Contemporary 90-day mortality rates after radicalcystectomy in the elderly. Eur J Surg Oncol. 2014; 40(12):1738-45.

11. Lambert JW, Ingham M, Gibbs BB, Given RW, Lance RS, Riggs SB. Using preoperative albumin levels as a surrogate marker for outcomes after radical cystectomy for bladder cancer. Urology. 2013; 81: 587-92.

12. Liu K, Xu ZY, Meng JS, Fu GB, Gu S, Gu M. Impact of preoperative nutritional risk on complications after radical cystectomy. Beijing Da Xue Xue Bao Yi Xue Ban. 2015; 47(5): 800-3.

13. Smith I, Kranke P, Murat I, Smith A, O'Sullivan G, Soreide $E$, et al. Perioperative fasting in adults and children: guidelines from the European Society of Anaesthesiology. Eur J Anaesthesiol. 2011; 28(8): 556-69.

14. Nygren J, Thacker J, Carli F, Fearon KC, Norderval S, Lobo DN, et al. Guidelines for perioperative care in elective rectal/pelvic surgery: Enhanced Recovery 
After Surgery $\left(\operatorname{ERAS}\left({ }^{\circledR}\right)\right)$ Society recommendations. World J Surg. 2013; 37(2): 285-305.

15. Bjornsson O, Gudmundsson EO, Marteinsson VT, Jonsson E. Radical cystectomy in the treatment of bladder cancer in Iceland: A population-based study. Scand J Urol. 2016; 50(1): 65-70.

16. Bochner BH, Dalbagni G, Sjoberg DD, Silberstein J, Keren Paz GE, Donat SM, et al. Comparing open radical cystectomy and robot-assisted laparoscopic radical cystectomy: A randomized clinical trial. Eur Urol. 2015 Jun; 67(6): 1042-50.

17. Tzortzis V, Dimitropoulos K, Karatzas A, Zachos I, Stamoulis K, Melekos M, et al. Feasibility and safety of radical cystectomy under combined spinal and epidural anesthesia in octogenarian patients with ASA score $>/=3$ : A case series. Can Urol Assoc J. 2015; 9(7-8): E500-4.

18. Bjornsson O, Gudmundsson EO, Marteinsson VT, Jonsson E. Radical cystectomy in the treatment of bladder cancer in Iceland: A population-based study. Scand J Urol. 2016; 50(1): 65-70.

19. Altobellia E, Buscarinia M, Gillb HS, Skinner EC. Readmission rate and causes at 90-day after radical cystectomy in patients on early recovery after surgery protocol. Bladder Cancer.2017; 3(1):51-6. 